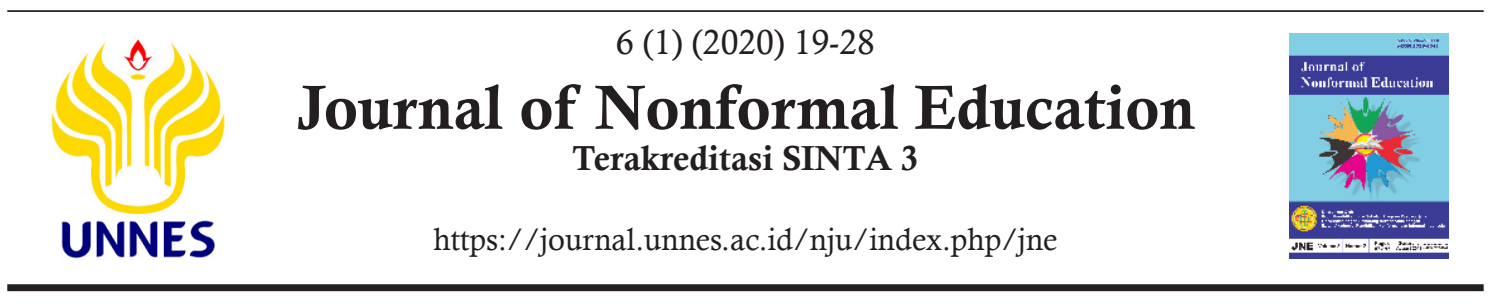

\title{
Participants in the Elderly Empowerment Program Posyandu Ngudi Utomo: Study in Indonesia
}

\author{
Abdul Malik $^{\bowtie}$, Ghanis Putra Widhanarto, Adhe Mella Vitriani
}

DOI: http://dx.doi.org/10.15294/jne.v6i1.22592

Universitas Negeri Semarang, Indonesia

\section{History Article}

Submitted 19 December 2019 Revised 24 January 2020 Accepted 4 February 2020

\section{Keywords}

old age empowerment; elderly health risks; posyandu's; enthusiasm factor

\begin{abstract}
Creating healthy, independent, quality and productive older adults can be performed through routine health care efforts, namely the need to pay attention to risk factors to improve the health of the elderly. This study aims to explain the process of empowering the elderly, explain the supporting and inhibiting factors in the process of allowing the elderly, and explain the outcomes of the elderly empowerment program through the posyandu. This qualitative study uses the subject of Posyandu management, posyandu's cadres for elderly and elderly families. Data analysis is shown in an interactive model by describing complete description data. The results showed that the process of empowering the elderly starts from preparation, assessment, planning alternative programs, formulating action plans, implementation and evaluation; while supporting factors are enthusiastic elderly who are high enough to know the health and support of the elderly family. Awareness is still low even there is a lack of infrastructure. The implication of this research for the field of community empowerment studies is to provide the benefits of preliminary studies for the development of betterquality empowerment models.
\end{abstract}

Correspondence Author:

E-mail: abdul.malik@mail.unnes.ac.id
p-ISSN 2442-532X e-ISSN 2528-4541 


\section{INTRODUCTION}

Transform technology in Older adults is shown in various countries in the world, even those who are unproductive according to performance factors sometimes become obstacles for developed countries to evenly. The scheme of regenerating urban communities is very progressive. It was stated in American reports a financial gain that democracy aims are to supports urbanisation rules (MacLeavy, 2009). The events in America are not different from events in other countries, for example, Indonesia; most urban communities are migrants who bring a lot of old age during the transfer to other regions so that it requires strict regulations from the government to manage this.

The report of a study (Zimmerman, et al., 1992) states that a person's intrapersonal abilities are affected by the empowerment of psychological aspects of each community group, but this is also primarily determined by participation in group activities from each. The empowerment strategy is to foster an identity to loyalty of local community. Locality is the key to mobilization of community development projects (Diyenti, 2019). Referring to the report (Zimmerman et al., 1992) it is necessary to approach the perception of businesses in the community as a positive long-term strengthening process.

Community empowerment is a program designed as a strategy to enhance standard of living of community through the process of capacity building, initiative and community participation (Hidayat \& Syahid, 2019). A large number of older adults is a burden if the elderly has health problems that increase the cost of health services, a decrease in income/income, an increase in disability, the absence of social and environmental support that is not friendly to the elderly population.

An increase in population has occurred in various countries, both developed and developing countries. Indonesia as the fourth most populous country in the world, after China, India and the United States, and most in the Southeast Asia region from 10 countries that are members of ASEAN. No exception of the elderly population has increased until 2015 to 21,511,855 people (Badan Pusat Statistik (Central Bureau of Statistics), 2015). The growth rate of Indonesia's elderly population from 2010-2015 is 0.36 per cent per year, while the rate of growth of the older adults of Central Java Province is 0.33 per cent per year.

The problem faced by the Indonesian people at this time is not only the increasing birth rate but also faces a double burden with the increase in the number of older adults due to the higher life expectancy (Bloom et al., 2015). This statement has increased the dependency rate of the elderly where every productive age population will bear more and older adults. Over time, old age is a natural process that cannot be avoided by anyone.

The population in Central Java Province is $33,774,140$ people with a population growth rate per year from 2010-2015 which is 0.81 per cent, while Banyumas Regency has a population of $1,635,910$ with a population growth rate per year from 2010-2015 which is 0 , 99 per cent (BPS Provinsi Jawa Tengah, 2016) we studied two groups of BALB/c mice: a nonimmunized control group ( $n=8$. No exception of the elderly population has increased until 2015 to $21,511,855$ people (Badan Pusat Statistik (Central Bureau of Statistics), 2015). The growth rate of Indonesia's elderly population from $2010-2015$ is 0.36 per cent per year, while the rate of growth of the older adults of Central Java Province is 0.33 per cent per year.

The elderly group facility is known as the Integrated Service Post (Posyandu) is a community-based health service facility to serve the elderly population (Pakasi, Korah, \& Imbar, 2016); whose process of formation and implementation is carried out by communities together with nongovernmental organizations, government and non-governmental sectors, private, social organizations and others, with a focus on health services on promotive and preventive efforts aimed at improving the quality of life through improving health and well-being (Fitriyah, et al., 2019).

Most of the elderly population in Indonesia still live in one household together with its extended family. 35.62 per cent of the elderly population lives with three generations in one home, and 26.84 per cent of the elderly population lives with the nuclear family in one household. Only about 8.90 per cent of the older adults lived alone, and 19.96 per cent lived with their partners in Central Jakarta Central Bureau of Statistics (Badan Pusat Statistik (Central Bureau of Statistics), 2015). In line with this, most families are still willing to care for the elderly, but there are still older adults who are ignored because they are not families who care for the elderly.

Health Act No. 36 of 2009 Article 139 says that the government is obliged to guarantee the availability of health service facilities and facilitate the elderly to be able to continue to live independently and productively socially and economically (Law, 2009). Therefore, efforts to provide health services to the elderly are needed by forming Integrated Service Posts or Elderly Integrated Development Post. Health care for the elderly 
aims to improve the health and quality of life of the elderly to achieve a happy and useful old age in the life of the family and society according to their existence.

Creating healthy, independent, quality and productive elderly can be treated as early as possible during the human life cycle until they enter the elderly phase by taking into account risk factors that must be avoided and protective factors that can be done to improve the health of the elderly (Clark et al., 2012). There is an awareness that it is time to appreciate the elderly by being fair, which cannot be equated with the treatment of children and adolescents. The need to have a mechanism to empower the elderly according to their age, help them through the stages of development (Villar, 2012), and include it in the process of transforming moral education.

Having achieved the authority of procedures, programs and activities require the involvement of the roles and responsibilities of the government, society, institutions, and social organisations to be committed to achieving prosperity for the elderly (Villar, 2012). This effort can be made by empowering the elderly to actively participate in development to reduce poverty, obtain better health and support social life through empowering the elderly who still pay attention to function, wisdom, knowledge, expertise, skills, experience, age, and physical condition.

In line with the negative circle of life, there is the essence of experience in the face of death resulting in the elderly withdrawing from society. According to Sudarma (2008) Theory of (Disengagement Disengagement Theory), old age is a process that moves slowly from individuals to withdraw from social roles or social contexts. This situation causes the interaction of elderly individuals to begin to decline, both in terms of quality and quantity.

Health services are carried out through increasing counselling and disseminating health information, healing efforts and developing care institutions for older adults who suffer from chronic diseases and terminal diseases. Health services for the elderly are carried out through several levels, namely health services at the community level (posyandu seniors), primary level (Public health) and advanced level (hospitals) (Kariman, et al., 2012).

According to Crain (2007) as age increases, contemplation and reflection of inner images naturally play a more significant role in human life. In old age, humans began to let their memories lay before their eyes. At this age, people try to understand the nature of experience in the face of death. In line with this, the problems posed by the increasing number of older adults, according to Hardywinoto \& Setiabudhi, (2005), not all older adults complain about things, and if there are complaints raised by elderly individuals, they need to be interpreted differently. Because of each of these complaints, even though they have the same disease problems, they will appear differently depending on their maturity and the elderly socio-economic situation.

Community empowerment is a process whereby communities, especially those who lack access to development resources, are encouraged to increase independence in developing their lives (Aziz, et al., 2005). Elderly Integrated Service Post (Posyandu) in Banyumas Regency becomes relevant as the subject of this study because Ngudi Utomo Posyandu has a public building which is not carried out in people's homes so that activities can be carried out maximally with adequate building availability. Costs are not charged to the elderly who are present but are charged to the citizens in each month; this is meant for all the elderly who are always current, especially the disadvantaged elderly.

The purpose of the study was to uncover the process of empowering the elderly through Posyandu, identifying the supporting and inhibiting factors that influence the empowerment of the elderly through posyandu's and outlining the results obtained by allowing the elderly through Posyandu. The implication of this research for the world of education, especially in the field of community empowerment studies, is to provide the benefits of preliminary studies for the development of better-quality empowerment models.

\section{METHODS}

This study uses qualitative methods and descriptive approaches, revealing detailed information from the aspects identified as activities in the implementation of the elderly empowerment program. Data on interviews, observations and documentation were arranged in objective analysis, then data reduction was carried out using triangulation as a data validity requirement. The subjects of this study were five elderly while supporting informants were one manager and two posyandu's cadres for the elderly, then three elderly families.

\section{RESULTS AND DISCUSSION}

Empowerment in society is a strategy to support community development and through 
community empowerment can participate in development (Herawaty \& Dalimunthe, 2017). The learning process in the context of community empowerment will take place gradually. Based on the results of interviews with research subjects obtained data that the process of empowering the elderly includes preparation, assessment, planning alternative programs, formulating action plans, implementation and evaluation (Noe, et al., 2015). This study also applies the stages in accordance with the theory obtained.

Preparation for empowerment is twofold, namely staff preparation and field preparation. Ngudi Utomo IHC in the training of officers began with the election of officers. The selection of tasks at the posyandu is the selection of cadres. The choice of organisations is carried out voluntarily and on the call of the heart, appointed by the hamlet in an association, each RT representing several people to be divided into tasks in BKB, $\mathrm{BKL}$, toddler posyandu and elderly posyandu. There is no requirement to become a cadre. Cadres have never participated in any training, but organisations always attend Coordination Meeting held in the urban village and Public health, so the activities carried out are directions from the Public health and urban town.

So that it is appropriate in terms of equalising perceptions because it has conducted a coordination meeting in advance with the Public health and urban village. In line with the preparation of officers according to (Adi, 2013) is a prerequisite for the success of community development with a non-directive approach. The training of these officers is mainly needed to equalise perceptions among team members as actors of change regarding what procedure to be chosen in carrying out community development. As process, empowerment is a series of activities for strengthen group power or empowerment weak in society, including individuals who experience poverty problems (Kurniawan, 2013). While site preparation, the location selected for the empowerment of the elderly at the elderly posyandu was quite strategic with the distance from RT 1 to RT 7 which was not too far away and affordable and had been provided by the hamlet building which was loose at the meeting hall at RT 05 . That officer who will conduct field preparations are initially carried out through feasibility studies of the areas to be targeted, both informally and formally (Adi, 2013).

Assessment, based on the research carried out SWOT technique with the strength that is in Hamlet 2 Kranji Village in the form of a humorous community, a large number of elderly and existing cadres. Weaknesses in hamlet 2 Kranji
Village are in the way of the absence of a particular health centre for the elderly in Hamlet 2, and there is only one in Kranji Village. The opportunity in Hamlet 2 of Kranji Village is supported by the Public health and the urban village to establish health centres for the elderly. The threat in Hamlet 2 in Kranji Village is in the form of another health centre with more complete facilities and infrastructure. By the statement that the process assessment carried out is by identifying problems or expressed needs and also the resources possessed by the target (Adi, 2013).

The Posyandu for the elderly Ngudi Utomo has a problem that is being faced. There is still doubt in the community to build a health centre for the elderly and the elderly who have to queue long if they have health checks at the Public health. The solution is to establish a forum to be able to handle the elderly who are sick as early as possible and help the needier elderly. In line with the statement (Angelis \& Jordahl, 2015) little known about the management practices in elderly care and exercise are associated with better performance. Knowing this would be valuable, not least given the common argument that is difficult to procure services when quality is difficult to measure, which says that the need to know elderly care management is precious.

All of this was done to increase the interest of the elderly to come to the posyandu for the elderly who had recently faded. An alternative program for Bina Keluarga Tua (BKL), which is not only an activity in the field of health, there are also activities in the spiritual area, namely pengajian. Also, there are also elderly posyandu held by PMI. Complete facilities and can meet older adults outside the scope of hamlet. In line with Rifa'i's statement (Rifa'i, 2008), the local development process is to enable the community to solve problems cooperatively and self-awareness. The social action strategy aims to allow society to work together to explore and change community power relations. Concerning relations between community members and outside authorities, local development implements collaboration and collaboration, while social actions apply competition or conflict.

The formulation of the action plan contains the objectives of the Posyandu, namely, to improve the welfare of the elderly through improving health with a health check-up, as a place of friendship because it can meet older adults in one hamlet and draw experience through counselling and elderly exercise. In accordance with (Sulistyorini, et al., 2010) the goal of the establishment of elderly posyandu is to improve the health and 
Table 1. The process of empowering the elderly through the Ngudi Utomo posyandu's

\begin{tabular}{ll}
\hline Empowerment Process & Research Results \\
\hline Preparation &
\end{tabular}

a. Preparation of officers

b. Field preparation

Assessment

a. The strength of the

b. Weaknesses

c.Opportunities

d. Threats

Program alternative planning

a. Problems faced

b. How to solve the problem

c. Alternative

Perform the action plan

a. Purpose

b. The target of

Implementation

a. Task cadre

b. The task of medical personnel
The selection of cadres is conducted out voluntarily and upon the call of the heart, appointed by the hamlet in an association. There is no requirement to become a Ngudi Utomo Posyandu cadre.

The location chosen for the empowerment of the elderly at the posyandu's in the elderly is quite strategic with the distance from RT 1 to RT 7 which is not too far away and affordable and has been provided by the hamlet building that is loose at the meeting hall at RT 05.

fun people, there is a lot of freedom, and there are cadres

There is no health centre for the elderly, especially in Kranji Village, there is only one.

Support from Public health so that close health centres can be organised.

Other health centres have more complete facilities and infrastructure.

There are still doubts in the community to build a health centre for the elderly and the elderly who have to queue long if they have health checks at the Public health.

A container is held to be able to handle older adults as early as possible and help the needier elderly.

Programs for the Elderly Family Development Program (BKL), which are not only activities in the health sector, there are also activities in the spiritual field, i.e. "pengajian" and posyandu seniors held by PMI. Complete facilities and can meet older adults outside the scope of hamlet.

To improve the welfare of the elderly through improving health with the existence of a health check-up, as a venue for friendship because they can meet with older adults in one hamlet and draw on experience through counselling and elderly exercise.

The hamlet two community, which has an age of 55 years, did not rule out the possibility that pre-elderly people between $45-54$ years old were also targeted by the elderly Posyandu and participated in the Posyandu activity for the elderly Ngudi Utomo.

Registering the elderly, then weighing the body, measuring height, then taking notes and after that are told to sit then given extra food.

Measuring tension, monitoring by asking complaints experienced by the elderly, and another medical staff is a health promotion that conducts counselling. 


c. Activities
The activity time is every month on the first Tuesday at the meeting
gymnastics for the elderly and health counselling. Gymnastics in
the elderly posyandu's is gymnastics while singing and gymnastics
for the elderly such as cholesterol gymnastics. The advice given at
the Posyandu at the Ngudi Utomo elderly community is counsel-
ling on nutrition and diseases experienced by the elderly.
Elderly can take part in all activities in the posyandus for the el-
derly. After gymnastics, the cadre asks the elderly about whether or
not the elderly can do the movements on the gymnastics themselves
and at the next meeting questions about gymnastics to provoke
the memory of the elderly. Having Evaluating counselling, cadres
asked in the next meeting, practised not at home, and carried out
a Q \& A by the instructor to find out the practice of the material
presented.

Source: Processed from primary data, 2017

quality of elderly health services in the community, to achieve a happy and efficient old age for families, and to bring services and increase public and private participation in health services in addition to improving communication between the elderly. The target is hamlet two communities who have 55 years of age, do not rule out the possibility that the elderly posyandu also targets pre-elderly people between 45-54 years old and participate in the posyandu activities. Visits to older adults who are no longer able to attend every month have also been carried out for several months. Based on observations, an appointment was made at Ms Warsitem's house. Ms Warsitem experienced a receipt, and indeed before experiencing illness she had been diligent in going to the posyandu for the elderly, but in the past year due to illness, she had been unable to attend the elderly posyandu every month. Following (Pudiastuti, 2011) these targets are a) pre-elderly (45-49 years), b) aged (50-69 years), c) High risk elderly (over 70 years).

This implementation stage is one of the most critical steps in community development because something that has been designed well will deviate from implementation in the field if there is no collaboration between actors of change and community members, as well as cooperation between citizens. Application, the cadre's task is to register the elderly, then weigh the weight, measure the height, then do the recording in the KMS and after that are told to sit then given extra food. Based on the results of the observation, the cadres also made a home visit to the elderly who were no longer able to attend the posyan$\mathrm{du}$ due to a sore throat. Following the division of services in the elderly posyandu according to (Pudiastuti, 2011) includes; a) implementation of weighing and measuring $\mathrm{BB}$ and $\mathrm{TB}, \mathrm{b}$ ) filling in elderly KMS, c) counselling and counselling, home visits, sports (elderly gymnastics). The task of medical staff is to measure tension, monitor, by asking complaints experienced by the elderly, and other medical personnel is a health promotion that conducts counselling.

Meanwhile, as for the duty of medical staff according to (Pudiastuti, 2011), namely; a) periodic health checks (once every three months), b) counselling and health counselling (once every three months), c) guidance for elderly health cadres. The time of the activity is every month on the first Tuesday at the meeting hall of hamlet 05 hamlets 2, Kranji Village. Existing businesses are gymnastics for the elderly and health counselling. Gymnastics in the elderly posyandu is gymnastics while singing and gymnastics for the elderly such as cholesterol gymnastics.

The advice given at the Posyandu at the Ngudi Utomo elderly community is counselling on nutrition and diseases experienced by the elderly. In line with (Sucipto, \& Sutarto, 2015) the implementation of a program must be carefully arranged in accordance with the time of activity, time period, place, participants, resource persons and material directed to people should be well prepared and arranged so that the implementation can be, planning, and smoothly in accordance with what has been planned and expected beforehand. There are also health checks recorded in the KMS to detect disease early, and health consultation by expressing complaints that have been encountered. Following what was revealed according to (Sucipto, \& Sutarto, 2015) these activities include a promotion, namely efforts to improve health, such as counselling healthy living behaviour, advanced nutrition to enhance physical 
fitness, and preventive efforts to prevent disease, detect early disease using Elderly KMS.

Evaluation is that the elderly can take part in all activities in the elderly posyandu. Here is due to good cooperation between the elderly, cadres and medical personnel when conducting an action. Organisations and medical staff who are patient and resilient provide examples and provide useful information. After gymnastics, the force asks the elderly about whether or not the elderly can do the movements on the gymnastics themselves and at the next meeting questions about gymnastics to provoke the memory of the elderly. In an Evaluating counselling, cadres asked in the next meeting, practised not at home, and conducted $\mathrm{Q} \& \mathrm{~A}$ by the instructor to find out the practice of the material presented. By what was disclosed by (Adi, 2013) evaluation as a process of oversight of citizens and officers of the ongoing program on community development should be carried out by involving citizens. Assessments are carried out not only to evaluate the results of changes but also to see the intervention process. Elderly Posyandu in requiring citizens to conduct supervision involves elderly cadres. There are two kinds of factors that influence empowerment, namely internal and external factors.

Internal factors are the influencing factors found in the elderly posyandu while internal factors are all factors that come from outside the posyandu. Internal factors, supporting elements, namely the enthusiasm of the elderly who are high enough to know health, To get high spirit from the elderly to be able to attend each month, it must be of interest first. Interest according to
Walgito (2005) that is the motive that arises for older adults because the organism is attracted to the object as a result of exploration so that the plant has an interest in the object in question.

The inhibiting factor is the awareness of the elderly who are often still low, awareness of the importance of the elderly posyandu; this is in line with (Malik, et al., 2014), which resulted in the inconsistency of participants (elderly) in participating in empowerment (posyandu seniors). Increasingly visible with the decrease in the number of participants (elderly who attended the posyandu for the elderly). This awareness also starts from the knowledge of the elderly about the benefits of posyandu can be obtained from personal experience in their daily lives that are still low. Older adults will get counselling on how to live healthy with all the limitations or health problems inherent in them by attending posyandu activities. Knowledge of the elderly has increased with this experience, which is the basis for the formation of attitudes and can encourage their interest or motivation to always participate in the activities of the elderly Posyandu (Sulistyorini, et al., 2010). As well as how to overcome them, door prizes are held every few months and come to the elderly to want to go to the posyandu.

External factors, supporting factors support a form of assistance provided by others. Support is obtained by anyone, especially people like family, friends, and so on. There is support from the elderly family by reminding the time of the implementation of the elderly posyandu. Family support is one quite important thing; the inhibiting factors for facilities and infrastructure

Table 2. Supporting and inhibiting factors for empowering the elderly through posyandu's

Supporting factors Research results and inhibitors

\begin{tabular}{|c|c|}
\hline \multicolumn{2}{|l|}{ Internal factors } \\
\hline a. Supporting factors & Enthusiastic elderly high enough to know the health \\
\hline b. Factors inhibiting & $\begin{array}{l}\text { awareness of older adults who are often still low, knowledge of the impor- } \\
\text { tance of elderly posyandu. }\end{array}$ \\
\hline c. How to deal with a & $\begin{array}{l}\text { door prize held a few months and go to the elderly to want to come to the } \\
\text { posyandu for the elderly. }\end{array}$ \\
\hline \multicolumn{2}{|l|}{ External factors } \\
\hline a. Supporting factors & $\begin{array}{l}\text { Support from elderly families by reminding the time of the implementation } \\
\text { of the elderly posyandu }\end{array}$ \\
\hline b. Inhibiting factors & $\begin{array}{l}\text { Facilities and infrastructure are inadequate; there is no longer checking } \\
\text { blood sugar and drug administration. }\end{array}$ \\
\hline c. How to overcome & $\begin{array}{l}\text { procurement of facilities and infrastructure by taking from the old cash in } \\
\text { "Dawis" and "PKK". }\end{array}$ \\
\hline
\end{tabular}

Source: Processed from primary data, 2017 
Table 3. Results of empowering the elderly through Ngudi Utomo posyandu

\begin{tabular}{ll}
\hline $\begin{array}{l}\text { Results of empow- } \\
\text { erment of elderly }\end{array}$ & Results of research \\
\hline $\begin{array}{l}\text { Results of changes } \\
\text { in elderly people }\end{array}$ & $\begin{array}{l}\text { Elderly can do their gymnastic movements that have been given by cadres } \\
\text { or medical personnel. Older adults are more able to maintain their health, } \\
\text { take care of themselves and be more independent. Older adults understand } \\
\text { about their health, reduce what should not be done and be eaten, besides } \\
\text { that the elderly become happy to be unsaturated and rarely emotion due to } \\
\text { counselling, and the elderly become many friends because at posyandu's the } \\
\text { elderly become an arena for old friendship within the hamlet. }\end{array}$ \\
\hline
\end{tabular}

Source: Processed from primary data, 2017

are inadequate; there is no longer checking for blood sugar and drug administration. In accordance with the statement of Sulistyorini, et al. (2010), to facilitate the implementation of activities at the elderly posyandu, supporting facilities and infrastructure are needed, namely: place of action (building, room or open space), tables and chairs, stationery, activity recording books, adult scales, meter height measurement, stethoscope, tensimeter, equipment, simple laboratory, thermometer, and the Towards Healthy Card (KMS) elderly. And how to overcome the procurement of facilities and infrastructure by taking from the old cash (Dawis and PKK).

\section{Outcomes of the elderly empowerment pro- gram through Posyandu}

The results of empowerment are all things obtained during the empowerment program through the posyandu. Gymnastics is one of the activities carried out in the posyandu. Various exercises carried out at the posyandu are finger gymnastics, heart exercises, and there are even gymnastics to train muscle strength. Cadres can supervise during gymnastics activities. Elderly can do their gymnastic movements that have been given by organisations or medical personnel. Inevitably, cadres have forgotten the gymnastics movement, from some older adults reminding what actions to do afterwards. Can also be seen with the high enthusiasm of the elderly in doing gymnastics. Supervision can also be carried out by other communities; in this case, an elderly family. According to several elderly families, the elderly can do their exercise by seeing the elderly routinely attend the posyandu for the elderly and never complain about gymnastics even though they have never been tried alone at home.

In addition to gymnastics, the activities at the posyandu are counselling. Counselling is carried out by medical personnel who are health promoters from Public health. There is information that can be applied by the elderly regarding the health of the elderly. Older adults are more able to maintain their health, take care of themselves and be more independent. Older adults understand about their health, reduce what should not be done and be eaten, besides that the elderly become happy to be unsaturated and rarely emotion due to counselling, and the elderly become many friends because at posyandu the elderly become an arena for old friendship within the RW. In line with (Leung, et al., 2016) causing significant increases in the demand for public housing. Normally, the elderly rely heavily on the facilities available in their living environment to maintain their quality of life (QoL which states that older adults who are too saturated live in the home. The elderly spend most of their time in the house. By the specific objectives expressed by Sulistyorini,et al. (2010) are a) increasing awareness of the elderly, b) fostering their health, c) improving the quality of health of the elderly, d) improving health services for the elderly.

With the posyandu, the elderly become more independent, by the independent understanding psychologically and mentally according to Basri (2000) namely the condition of someone who in his life can decide and do something without the help of others. Mandiri referred to in this study is independent in the health aspect, as stated by Maryam, et al (2008) that a form of measurement of a person's ability to carry out daily life activities independently. Determination of functional independence can identify skills and limitations. Thus, the elderly with the right health conditions can carry out more events than the elderly with low health.

\section{CONCLUSIONS}

Conclusion of this article is that the process of empowering the elderly through Ngudi Utomo posyandu has been carried out with the preparation stage in the form of staff and field 
preparation, assessment, alternative program planning, formulation of action plans, implementation (program), process evaluation and results of changes. Supporting factors and obstacles to the empowerment of the elderly through the elderly posyandu consist of internal factors, namely the enthusiasm of the elderly to know health and external factors, namely support from others. The results of empowering the elderly can provide benefits to maintain their health, care for themselves and be more independent.

\section{REFERENCES}

Adi, I. R. (2013). Intervensi Komunitas \& Pengembangan Masyarakat Sebagai Upaya Pemberdaya Masyarakat. Jakarta: PT RajaGrafindo Persada.

Angelis, J., \& Jordahl, H. (2015). Merciful yet effective elderly care performance management practices. Measuring Business Excellence, 19(1), 61-69. https://doi.org/10.1108/MBE-11-2014-0046

Aziz, M. A, Suhartini \& Halim, A. (2005). Dakwah Pemberdayaan Masyarakat: Paradigma Aksi Metodologi. Yogyakarta: LKis Pelangi Aksara.

Badan Pusat Statistik (Central Bureau of Statistics). (2015). Profil Penduduk Indonesia Hasil SUPAS 2015. Badan Pusat Statistik. Retrieved from https://www.bps.go.id/publication/download.html?

Basri, H. (2000). Faktor dalam Disiplin Diri. Jakarta: Gramedia.

Bloom, D. E., Chatterji, S., Kowal, P., Lloyd-Sherlock, P., McKee, M., Rechel, B., ... Smith, J. P. (2015). Macroeconomic implications of population ageing and selected policy responses. The Lancet, 385(9968), 649-657. https://doi. org/10.1016/S0140-6736(14)61464-1

BPS Provinsi Jawa Tengah. (2016). Provinsi Jawa Tengah Dalam Angka 2016. BPS Provinsi Jateng, 411.

Clark, F., Jackson, J., Carlson, M., Chou, C. P., Cherry, B. J., Jordan-Marsh, M., ... Azen, S. P. (2012). Effectiveness of a lifestyle intervention in promoting the well-being of independently living older people: Results of the Well Elderly 2 Randomised Controlled Trial. Journal of Epidemiology and Community Health, 66(9), 782-790. https://doi.org/10.1136/jech.2009.099754

Crain, W. (2007). Teori Perkembangan: Konsep dan Aplikasi. Terjemahan Yudi Santoso. Yogyakarta: Pustaka Pelajar

Diyenti, A. K., \& Rakimahwati, R. (2019). The Influence of Traditional Games and Gender on Children's Motoric Physical Development. Journal of Nonformal Education, 5(2), 58-64. https://doi.org/10.15294/jne.v5i2.20204

Fitriyah, A., Purbowati, N., \& Follona, W. (2019). Faktor-Faktor yang Berhubungan Dengan Kunjungan Ibu Dengan Balita ke Posyandu. SEAJOM: The Southeast Asia Journal of Midwifery, 5(2), 79
83. https://doi.org/10.36749/seajom.v5i2.73

Hardywinoto \& Setiabudhi, T. (2005). Panduan Gerontologi. Jakarta: Gramedia Pustaka Utama.

Herawaty, H., \& Dalimunthe, B. (2017). Government Role of Urban Poor Community Empowerment Program in DKI Jakarta. Journal of Nonformal Education, 3(2), 97-109. https://doi. org/10.15294/jne.v3i2.10944

Hidayat, D., \& Syahid, A. (2019). Local Potential Development (Local Genius) in Community Empowerment. Journal of Nonformal Education, 5(1), 1-14. https://doi.org/10.15294/jne. v5i1.18343

Kariman, E. R., Resnayati, Y., Sofyan, N. S., \& Riasmini, M. (2012). Pelayanan Kesehatan di Wilayah DKI Jakarta ( The Elderly' s Experience In Utilization of Health Services In Jakarta ). Jurnal Keperawatan, 1(2), 141-156.

Kurniawan, D. A. (2013). Proses Pemberdayaan Perempuan Melalui Pelatihan Keterampilan oleh Badan Pemberdayaan Masyarakat, Perempuan dan Keluarga Berencana Kabupaten Sidoarjo. PUblika, 3(4), 1-17.

Law, I. M. of. Undang-undang RI Nomer 36 Th 2009 tentang Kesehatan, Indonesia Ministry of Law $\S$ (2009). Indonesia.

Leung, M. Y., Yu, J., \& Chow, H. (2016). Impact of indoor facilities management on the quality of life of the elderly in public housing. Facilities, 34(9-10), 564-579. https://doi. org/10.1108/F-06-2015-0044

MacLeavy, J. (2009). (Re) analysing community empowerment: Rationalities and technologies of government in Bristol's new deal for communities. Urban Studies, 46(4), 849-875. https://doi. org/10.1177/0042098009102132

Malik, A. \& Irene, S. (2014). Keberhasilan Program Desa Vokasi terhadap Pemberdayaan Masyarakat di Desa Gemawang Kabupaten Semarang. Jurnal Pendidikan Dan Pemberdayaan Masyarakat, 1(2), 124-135.

Maryam, S., Ekasari, M. F., Rosidawati, Jubaedi, A., Batubara, I. (2008). Mengenal Usia Lanjut dan Perawatannya. Jakarta: Salemba Medika.

Noe, R. A., Hollenbeck, J. R., Gerhart, B., \& Wright, P. M. (2015). Human Resource Management: Gaining Competitive Advantage. Human Resources Management, 1(1), 1-7.

Pakasi, A., Korah, B. H., \& Imbar, H. S. (2016). Hubungan Pengetahuan Dan Sikap Kader Kesehatan Dengan Pelayanan Posyandu. Jurnal Ilmiah Bidan, 4(1), 15-21.

Pudiastuti, R. D. (2011). Penyakit Pemicu Stroke: Dilengkapi dengan Posyandu Lansia dan Posbindu PTM. Yogyakarta: Nuha Medika.

Rifa'i, A. (2008). Pemberdayaan Masyarakat melalui Pendidikan Nonformal. Semarang: UNNES Press.

Sudarma, M. (2008). Sosiologi untuk Kesehatan. Jakarta: Salemba Medika.

Sucipto, N. R., \& Sutarto, J. (2015). Pemberdayaan Masyarakat Miskin untuk Meningkatkan Kecakapan Hidup Melalui Kursus Menjahit di 
Abdul Malik et al. / Journal of Nonformal Education 6 (1) (2020) 19-28

LKP Elisa Tegal. Journal of Nonformal Education and Community Empowerment, 4(2), 1-8.

Sulistyorini, C. I., Pebrianti, S., Proverawati, A. (2010). Posyandu (Pos Pelayanan Terpadu) dan Desa Siaga. Yogyakarta: Nuha Medika.

Villar, F. (2012). Successful ageing and development: The contribution of generativity in older age. Ageing and Society, 32(7), 1087-1105. https:// doi.org/10.1017/S0144686X11000973
Walgito, B. (2005). Pengantar Psikologi Umum. Yogyakarta: Andi Offset.

Zimmerman, M. A., Israel, B. A., Schulz, A., \& Checkoway, B. (1992). Further explorations in empowerment theory: An empirical analysis of psychological empowerment. American Journal of Community Psychology, 20(6), 707-727. https://doi.org/10.1007/BF01312604 